\title{
Human immunodeficiency virus type 1 neutralization by plasma from B or $F$ genotype infected individuals
}

\author{
V Bongertz/ ${ }^{+}$, SLM Teixeira, B Grinztejn*, JH Pilotto*, VG Veloso*, MG Morgado, \\ FI Bastos**, EP O uverney
}

\begin{abstract}
Laboratório de Aids e Imunologia Molecular, Departamento de Imunologia, Instituto Oswaldo Cruz-Fiocruz, Av. Brasil 4365, 21045-900 Rio de Janeiro, RJ, Brasil *Instituto de Pesquisa Evandro Chagas-Fiocruz, Rio de Janeiro, RJ **Centro de Informações Científicas e Tecnológicas-Fiocruz, Rio de Janeiro, RJ, Brazil
\end{abstract}

Anti-human immunodeficiency virus type 1 (HIV-1) "binding antibodies" (antibodies capable of binding to synthetic peptides or proteins) occur throughout HIV-1 infection, are high-titered and highly cross-reactive, as confirmed in this study by analyzing plasma from B and F genotype HIV-1 infected individuals. Plasma from individuals infected with clade F HIV-1 displayed the most frequent cross-reactivity, in high titers, while Bbr plasma showed much higher specificity.

Similarly, neutralization of a reference HIV-1 isolate (HIV-1 MN) was more frequently observed by plasma from $F$ than $B$ genotype infected individuals. No significant difference was seen in neutralization susceptibility of primary B, Bbr or F clade HIV-1 by plasma from individuals infected with the classical B (GPGR) or F HIV-1, but Bbr $(G W G R)$ plasma were less likely to neutralize the F genotype primary HIV-1 isolates.

The data indicate that both $B$ and $F$ genotype derived vaccines would be equally effective against $B$ and $F$ HIV-1 infection, with a slightly more probable effectiveness for F than B genotype. Although the Bbr variant appears to induce a much more specific humoral immune response, the susceptibility in neutralizing the Brazilian HIV-1 B genotype Bbr variant is similar to that observed with the classical B genotype HIV-1.

Key words: human immunodeficiency virus type 1 - neutralization - genotype - Brazil

Humoral immune response against human immunodeficiency virus type 1 (HIV-1) is extensive but is detectable only fairly late in infection, and may be of little importance in the control of the acute infection. Attempts to "immunotype", "serotype" or "neutrotype" HIV-1 have shown that, although "reactivity clusters" can be identified (Bradac \& Ho 1992, McKnight et al. 1992, Mascola et al. 1994, 1996, Cheingsong-Popov et al. 1994, Weber et al. 1996, Kostrikis et al. 1996, Zolla-Pazner et al. 1999, Zhang et al. 2002, Zolla-Pazner 2004), these have little correlation to the clades identified by genotyping HIV-1. In Southeastern Brazil, although infection by the so-called Brazilian variant of the classical B clade of HIV-1, Bbr, can mostly be distinguished by a more specific reactivity pattern towards homologous synthetic peptides, no distinction of plasma of individuals infected with the prevalent $B$ or the F clades of HIV-1 could be observed using synthetic envelope peptides (Bongertz et al. 2003).

The importance of the anti-HIV-1 humoral immune response has been a highly controversial subject since antibodies capable of neutralizing the virus were first described (Ho et al. 1985. Robert-Guroff et al. 1985, Weiss et al. 1985). In the course of the last three years, however, the high protection obtained in monkeys infused with antiHIV-1 monoclonal antibodies has increased interest in

Financial support: Faperj E-26/170.409/99, CNPq 33530/ 2000-0, WHO, Brazilian Ministry of Health

${ }^{+}$Corresponding author. E-mail: bongertz@ioc.fiocruz.br

Received 7 July 2004

Accepted 20 October 2004
HIV-1 neutralization (Baba et al. 2000, Mascola et al. 2000, Nishimura et al. 2002, Ferrantelli et al. 2004). Studies in animal models have confirmed the importance of HIV-1 neutralizing antibodies (NAb) in HIV-1 infection and efforts to analyze and to induce such antibodies in humans have been increased.

In the Southeast region of Brazil, genotypes B and $\mathrm{F}$ are the prevalent circulating HIV-1 subtypes. Little is known about cross-neutralization in Brazil, and the present analysis attempts to compare the neutralization potency of antibodies in plasma from individuals infected with B (comprising the classical B genotype displaying the amino acid sequence GPGR at the tip of the V3 loop (B-GPG)and the Bbr or B" variant, with GWGR at the tip of the V3 loop) or F genotype HIV-1, as well as an attempt to analyze the comparative neutralization susceptibility of B (GPG and GWG) and F HIV-1 primary isolates. This information is of fundamental importance for a rational choice of anti-HIV/ AIDS vaccination agents.

\section{MATERIALS AND METHODS}

A global analysis of several different projects, performed with approval of the Fiocruz Ethical Committee, is presented, mainly of a recent study carried out with plasma from injection drug users (IDU) (Bongertz et al. 2003). Plasma were obtained from 105 patients diagnosed as HIV-1 positive according to the norms of the Brazilian Ministry of Health, who were in all stages of HIV-1 infection ( $47.6 \%$ being asymptomatic individuals). Only a small number of the patients $(10.5 \%)$ were under antiretroviral therapy, as blood collected for diagnosis of HIV infection was used. The majority of the samples were obtained from male individuals (73.3\%). 
Seroreactivity to synthetic V3 envelope peptides was carried out using reagents and methods described earlier (Bongertz et al. 1999). Briefly, biotinylated decapentamer synthetic peptides corresponding to HIV-1 consensus amino acid sequences of HIV-1 genotypes A, B (including variant $\mathrm{Bbr}$ ), $\mathrm{C}, \mathrm{D}, \mathrm{E}$, and $\mathrm{F}$ (including an empirically chosen Brazilian sequence Fbr) were bound onto avidincoated immunoplates, incubated with duplicates of serially diluted sample and control plasma. Bound antibodies were evaluated after washing with $8 \mathrm{M}$, adding horse radish peroxidase labeled anti-human $\mathrm{IgG}$ (Fc specific) and the peroxide/TMB substrate/chromogen mixture color intensity was read at $450 \mathrm{~nm}$.

The methods used for HIV-1 neutralization in peripheral blood mononuclear cells (PBMC) (Bongertz et al. 2001) and the CEM T lymphocytic cell line (Bongertz et al. 2002) have been described previously. Briefly, serially diluted plasma specimens were incubated for $1 \mathrm{~h}$ at $37^{\circ} \mathrm{C}$ with 10 to 50 ID (infectious doses, previously determined, at least two dilutions used in each assay) of viral stock. Incubation with host cells was carried out for seven days (with two changes of culture medium after 24 and $48 \mathrm{~h}$ ). When primary HIV-1 isolates were employed, pre-activated normal human PBMC were prepared at a concentration of $10^{6} / \mathrm{ml}$. For analysis of the T-cell line adapted HIV-1 isolate MN, both PBMC and CEM cells $\left(10^{5} / \mathrm{ml}\right)$ were used. Neutralization was considered positive when a reduction of at least $75 \%$ of viral input was detected as measured by p24 concentration (Beckman-Coulter Co, San Diego, CA). Neutralization was evaluated at $50-89 \%$ and at $\geq 90 \%$ reduction of viral input as measured in positive control wells. The number of assays run for each isolate and the number of plasma tested varied, and are specified in the text for the different groups analyzed.

Determination of the genetic subtype of the HIV-1 isolates was carried out using the heteroduplex mobility assay (HMA) with the primers and technique described by Delwart et al. (1993). Identification of the Brazilian B subtype variant $\mathrm{Bbr}$ was carried out using Fok I restriction fragment length polymorphism determination (Morgado et al. 1998).

The Mann-Whitney two-tailed unpaired test was used for comparative evaluation of frequencies, and statistical significance established at $<5 \%$ (Instat Program, GraphPad, San Diego, CA).

\section{RESULTS}

Seroreactivity showed the very high extent of crossreactivity of the plasma samples with the synthetic peptides tested. Fig. 1 shows that plasma specimens from individuals infected with clade F HIV-1 display the most frequent reactivity not only with the homologous $\mathrm{V} 3 \mathrm{~F}$ peptide, but also with the heterologous $\mathrm{V} 3$ peptides used, in high titers, much higher than those displayed by BGPG clade plasma specimens. Indeed, all F plasma samples recognized, for example, the $\mathrm{V} 3 \mathrm{~B}$ peptide, which is recognized by only $85 \%$ of B-GPG plasma specimens. As indicated before (Bongertz et al. 1999), the Bbr plasma specimens showed much lower cross-reactivity with the different V3 peptides, and most high-titered reactions were observed against the homologous Bbr synthetic V3 peptide.

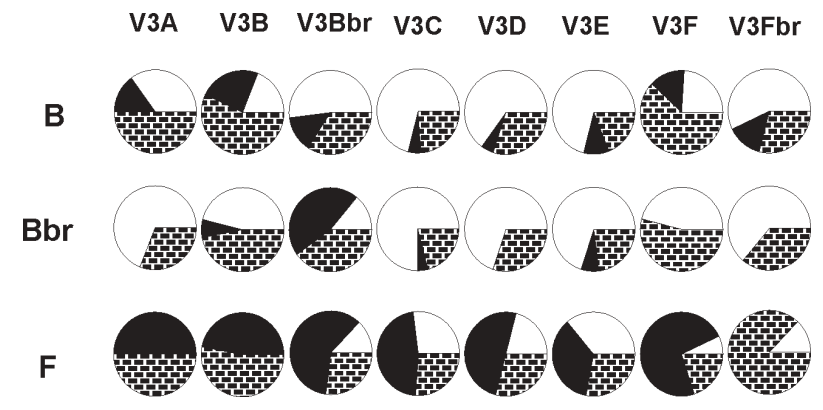

Fig. 1: percentage of plasma from individuals infected with $\mathrm{B}, \mathrm{Bbr}$ or F genotype human immunodeficiency virus type 1 (HIV-1) recognizing individual synthetic HIV-1 envelope V3 peptides corresponding to different HIV-1 genotypes/variant consensus sequences. Black areas indicate plasma with reactivities at 1:1000 or higher dilutions while chequered areas indicate plasmas with reactivities at dilutions below 1:1000.

Of greater interest would be if this extensive crossbinding activity was mirrored by extensive cross-neutralization, as this would be indicative of cross-protection, important for anti-HIV/AIDS vaccine research. Therefore, neutralization of primary HIV-1 isolates and of a T cell line adapted HIV-1 isolate by plasma specimens from individuals infected with the different HIV-1 genotypes/variant prevalent in southeastern Brazil was evaluated.

Neutralization of HIV-1 MN was more frequently observed by plasma specimens from the HIV-1 F genotype than B genotype infected individuals, however, due to the smaller number of $\mathrm{F}$ plasma specimens available for testing, no statistical analysis could be carried out.

Interestingly, a more frequent and more effective neutralization of HIV-1 MN replication in pre-activated human donor peripheral blood mononuclear cells (PBMC) $(\mathrm{p}=0.0290)$ and in a T-lymphocytic cell line (CEM) $(\mathrm{p}=$ 0.0247 ) was observed by Bbr variant plasma samples than by classical B genotype HIV-1 plasma specimens (Fig. 2).

No difference in neutralization of primary $\mathrm{B}$ clade HIV-1 $(n=33)$ by B $(n=151), B b r(n=66)$ or F $(n=35)$ plasma or of the HIV-1 Bbr isolates $(n=20)$ by $B(n=52)$, $\operatorname{Bbr}(\mathrm{n}=70)$ or $\mathrm{F}(\mathrm{n}=18)$ plasma samples at low dilutions (1:10) could be observed (Fig. 3). At higher dilutions (1:100,

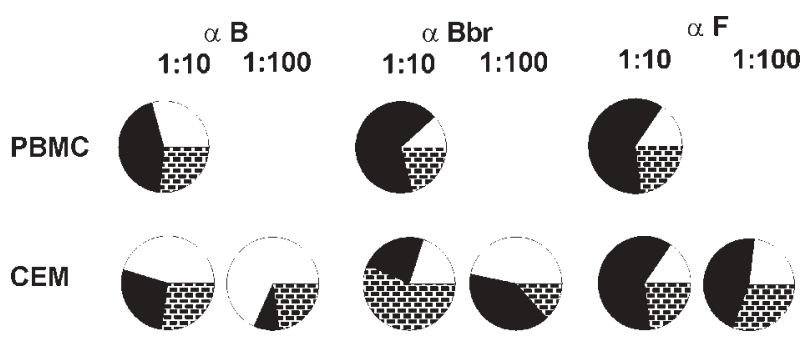

Fig. 2: neutralization of human immunodeficiency virus type 1 (HIV-1) MN replication in pre-activated peripheral blood mononuclear cells (PBMC) or a T lymphocytic cell line (CEM): Preincubation of HIV-1 MN with classical B-GPG $(\alpha B, n=72)$, the Brazilian variant Bbr $(\alpha \mathrm{Bbr}, \mathrm{n}=43)$ or $\mathrm{F}$ genotype plasma $(\alpha \mathrm{F}, \mathrm{n}=$ 13) at the dilutions of $1: 10$ or $1: 100$, as indicated. Black areas indicate neutralization of at least $90 \%$ of viral input, while chequered areas indicate neutralization of 50 to $89.9 \%$ of viral input. 
data not shown), F plasma samples were not as frequently effective against B clade HIV-1 isolates, but no statistical significance was observed.

Although only a limited number of primary HIV-1 F genotype isolates $(n=4)$ was available at the high activities needed for neutralization assays, they were also equally susceptible to B or F plasma specimens $(n=25$ and 14, respectively). However, plasma samples from individuals infected with the Brazilian Bbr variant of HIV-1 $(n=14)$ were less frequently able to neutralize the F genotype primary HIV-1 isolates $(\mathrm{p}=0.0409)$ (Fig. 3).

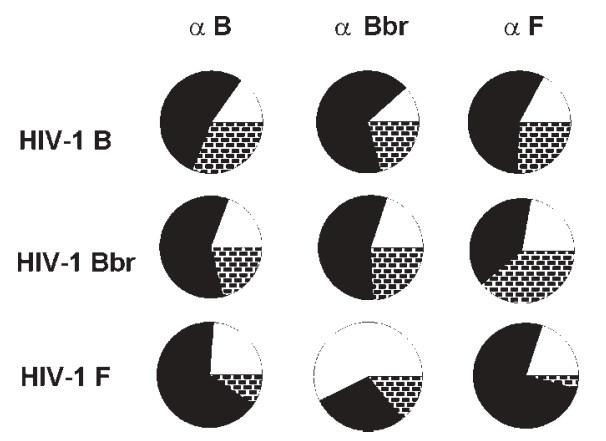

Fig. 3: neutralization of primary human immunodeficiency virus type $1(\mathrm{HIV}-1)$ isolates of clade $\mathrm{B}(\mathrm{n}=33)$, variant $\mathrm{Bbr}$ of clade $\mathrm{B}$ $(n=20)$ or of clade $F(n=4)$ by plasma from individuals infected with clade B $(\alpha \mathrm{B})$, Bbr variant of clade B $(\alpha \mathrm{Bbr})$ or HIV-1 clade F $(\alpha \mathrm{F})$. Areas in brick pattern indicate $50-89 \%$ neutralization of viral input, and areas in black indicate neutralization of $\geq 90 \%$ of viral input.

\section{DISCUSSION}

HIV-1 neutralizing antibodies have come again to the forefront of research since the recent demonstrations of their protective capacities (Baba et al. 2000, Mascola et al. 2000, Hofmann-Lehmann et al. 2001, Parren et al. 2001, Ruprecht et al. 2001, Nishimura et al. 2002, Ferrantelli \& Ruprecht 2002, Xu et al. 2002, Mascola 2002, Xiao et al. 2002, Ferrantelli et al. 2004). Moreover, their importance in the early control of HIV-1 infection is implied by the finding of immune complexes containing HIV-1 RNA(Dianzani et al. 2002), which could be an explanation for the disparity between quantification of viral RNA and of infectious HIV virions (Igarashi et al. 1999). Also, the increase in neutralization susceptibility of cultured HIV-1 and its decrease after inoculation indirectly confirms the control displayed by HIV-1 neutralizing antibodies in infection (Pugach et al. 2004). Another factor has been the growing conviction that the same kind of obstacles experienced in efforts to develop anti-HIV/AIDS vaccines dependent on neutralizing antibody induction are also true for vaccines dependent on stimulation of anti-HIV cellular immune response (i.e., HIV-1 variability, viral escape - Mascola et al. 2003). Therefore, nowadays the consensus is that the immune response to be induced by an anti-HIV/AIDS vaccine must include both humoral and cellular immune response, with specificities that are only now in the process of being defined.

One of the objectives of an effective anti-HIV/AIDS vaccine is that it should confer protection against all
HIV-1 genotypes prevalent in the areas where the vaccine is to be applied. In Brazil, B and F are the prevalent genotypes found, with an increasingly important occurrence of genotype C HIV-1 in the Southern region of the country. Therefore, the cross-protection among these genotypes has to be analyzed.

The data presented show that plasma from individuals infected with genotype F HIV-1 more frequently possess neutralizing antibodies able to neutralize not only the homologous $\mathrm{F}$ but also the heterologous B genotype HIV-1 primary isolates, similar to the more frequent crossbinding activity observed in plasma samples from $\mathrm{F}$ in comparison to B genotype HIV-1 infected individuals. This appears to be more significant when lower concentrations of antibodies are compared by using higher dilutions of plasma samples, both for binding and for neutralization activity of the antibodies, as exemplified by the very high neutralization potency of the majority of the plasma specimens from individuals infected with HIV-1 genotype F against the reference isolate HIV-1 MN.

Attempts to correlate extent of seroreactivity or neutralization with individual progression of HIV-1 infection were made but statistical analyses indicated that no difference in extent of clinical disease progression between individuals belonging to the group infected with clade $\mathrm{F}$ or B HIV-1 could be detected.

Of interest are the results observed with plasma from individuals infected with the Brazilian variant Bbr of B genotype HIV-1. Seroreactivity assays show a high specificity of binding by homologous plasma samples; but this specificity is a characteristic rather of the antibodies than of the epitopes recognized, as the synthetic V3 peptide correspondent to this variant is well recognized by the heterologous F plasma specimens. This might be interpreted as an indication that this viral variant is less able to induce an antibody response than are F genotype viruses, as also indicated by the less frequent neutralization of HIV-1 F genotype isolates by Bbr plasma samples.

HIV-1 F genotype appears to be specially antigenic and able to induce a more potent humoral immune response than that induced by the B genotype viruses. This may be linked to the exceptionally high capacity of F genotype HIV-1 to recombine with HIV-1 from other genotypes (Vicente et al. 2000), reflected by the low number of pure $\mathrm{F}$ genotype HIV-1 (Morgado et al. 2002), and the high percentage of $\mathrm{B} / \mathrm{F}$ recombinants described in Brazil (Guimarães et al. 2002). Therefore, further studies on the specific antiHIV-1 genotype F immune response are indicated.

\section{ACKNOWLEDGEMENTS}

To the Instituto Estadual de Hematologia Arthur de Siqueira Cavalcanti, for donation of human donor buffy coats.

\section{REFERENCES}

Baba TW, Liska V, Hofmann-Lehmann R, Vlasak J, Xu W, Ayehunie S, Cavacini LA, Posner MR, Katinger H, Stiegler G, Bernacky BJ, Rizvi TA, Schmidt R, Hill LR, Keeling ME, Lu Y, Wright JE, Chou TC, Ruprecht RM 2000. Human neutralizing monoclonal antibodies of the IgG1 subtype protect against mucosal simian-human immunodeficiency virus infection. Nat Med 6: 200-206

Bongertz V, Costa CI, Veloso VG, Grinsztejn B, João Filho EC, 
Calvet G, Pilotto JH, Guimarães ML, Morgado MG 2001. Vertical HIV-1 transmission: importance of neutralizing antibody titer and specificity. Scand J Immunol 53: 302309.

Bongertz V, Costa CI, Veloso VG, Grinsztejn B, João Filho EC, Calvet G, Pilotto JH, Guimarães ML, Morgado MG 2002. Neutralization titers and Vertical HIV-1 transmission. Scand J Immunol 56: 642-644.

Bongertz V, Guimarães ML, Soares-da-Costa MFG, Velosodos-Santos VG, The HEC/Fiocruz AIDS Clin Res Group, Bastos FI, Telles PR, Morgado MG 1999. Anti-HIV-1 seroreactivity in distinct transmission risk groups. $J$ Clin Virol 12: 27-36.

Bongertz V, Ouverney EP, Teixeira SLM, C Silva-de-Jesus, MA Hacker, MG Morgado, FI Bastos, The Brazilian Network for HIV Isolation and Characterization 2003. Higher antiHIV-1 antibody titers in injection drug users compared to sexually infected individuals. Mem Inst Oswaldo Cruz 98: 209-212.

Bradac J, Ho D 1992. Summary of the Antigenic Variation Working Group. AIDS Res Hum Retroviruses 8: 1419-1421.

Cheingsong-Popov R, Lister S, Callow D, Kaleebu P, Beddows S, Weber J 1994. Serotyping HIV type 1 by antibody binding to the V3 loop: relationship to viral genotype. WHO Network for HIV Isolation and Characterization. AIDS Res Hum Retroviruses 10: 1379-1386.

Delwart EL, Shpear EG, Louwagie J, Mc Cutchan FE, Grez M, Ruebsamen-Waigmann H, Mullins J 1993. Genetic relationships determined by a DNA heteroduplex motility assay: Analysis of HIV-1 env genes. Science 262: 1257-1261

Dianzani F, Antonelli G, Riva E, Turriziani O, Antonelli L, Tyring S, Carrasco DA, Lee H, Nguyen D, Pan J, Poast J, Cloyd M, Baron S 2002. Is human immunodeficiency virus RNA load composed of neutralized immune complexes? J Infect Dis 185: 1051-1054.

Ferrantelli F, Ruprecht RM 2002. Neutralizing antibodies against HIV - Back in the major leagues? Curr Opin Immunol 14: 495-502.

Ferrantelli F, Kitabwalla M, Rasmussen RA, Cao C, Chou TC, Katinger H, Stiegler G, Cavacini LA, Bai Y, Cotropia J, Ugen KE, Ruprecht RM 2004. Potent cross-group neutralization of primary human immunodeficiency virus isolates with monoclonal antibodies-implications for acquired immunodeficiency syndrome vaccine. J Infect Dis 189: 71-74.

Guimarães ML, dos Santos Moreira A, Loureiro R, GalvãoCastro B, Morgado MG; Brazilian Network for HIV Isolation and Characterization 2002. High frequency of recombinant genomes in HIV type 1 samples from Brazilian southeastern and southern regions. AIDS Res Hum Retroviruses 18: 1261-1269.

Ho DD, Rota TR, Schooley RT, Kaplan JC, Allan JD, Groopman JE, Resnick L, Felsenstein D, Andrews CA, Hirsch MS 1985. Isolation of HTLV-III from cerebrospinal fluid and neural tissues of patients with neurologic syndromes related to the acquired immunodeficiency syndrome. $N$ Engl J Med 313: 1493-1497.

Hofmann-Lehmann R, Rasmussen RA, Vlasak J, Smith BA, Baba TW, Liska V, Montefiori DC, McClure HM, Anderson DC, Bernacky BJ, Rizvi TA, Schmidt R, Hill LR, Keel- ing ME, Katinger H, Stiegler G, Posner MR, Cavacini LA, Chou TC, Ruprecht RM 2001. Passive immunization against oral AIDS virus transmission: an approach to prevent mother-to-infant HIV-1 transmission? J Med Primatol 30: 190-196.

Igarashi T, Brown C, Azadegan A, Haigwood N, Dimitrov D, Martin MA, Shibata R 1999. Human immunodeficiency virus type 1 neutralizing antibodies accelerate clearance of cell-free virions from blood plasma. Nat Med 5: 211-216.

Kostrikis LG, Cao Y, Ngai H, Moore JP, Ho DD 1996. Quantitative analysis of serum neutralization of human immunodeficiency virus type 1 from subtypes A, B, C, D, E, F, and I: lack of direct correlation between neutralization serotypes and genetic subtypes and evidence for prevalent serum-dependent infectivity enhancement. J Virol 70: 445458.

Mascola JR 2002. Passive transfer studies to elucidate the role of antibody-mediated protection against HIV-1. Vaccine 20: 1922-1925.

Mascola JR, Lewis MG, VanCott TC, Stiegler G, Katinger H, Seaman M, Beaudry K, Barouch DH, Korioth-Schmitz B, Krivulka G, Sambor A, Welcher B, Douek DC, Montefiori DC, Shiver JW, Poignard P, Burton DR, Letvin NL 2003. Cellular immunity elicited by human immunodeficiency virus type $1 /$ simian immunodeficiency virus DNA vaccination does not augment the sterile protection afforded by passive infusion of neutralizing antibodies. J Virol 77: 1034810356.

Mascola JR, Louwagie J, McCutchan FE, Fischer CL, Hegerich PA, Wagner KF, Fowler AK, McNeil JG, Burke DS 1994. Two antigenically distinct subtypes of human immunodeficiency virus type 1: viral genotype predicts neutralization serotype. J Infect Dis 169: 48-54.

Mascola JR, Louder MK, Surman SR, Vancott TC, Yu XF, Bradac J, Porter KR, Nelson KE, Girard M, McNeil JG, McCutchan FE, Birx DL, Burke DS 1996. Human immunodeficiency virus type 1 neutralizing antibody serotyping using serum pools and an infectivity reduction assay. AIDS Res Hum Retroviruses 12: 1319-1328.

Mascola JR, Stiegler G, VanCott TC, Katinger H, Carpenter CB, Hanson CE, Beary H, Hayes D, Frankel SS, Birx DL, Lewis MG 2000. Protection of macaques against vaginal transmission of a pathogenic HIV-1/SIV chimeric virus by passive infusion of neutralizing antibodies. Nat Med 6: 207-210.

McKnight A, Clapham PR, Goudsmit J, Cheingsong-Popov R, Weber JN, Weiss RA 1992. Development of HIV-1 groupspecific neutralizing antibodies after seroconversion. AIDS 6: 799-802.

Morgado MG, Guimarães ML, Galvão-Castro B 2002. HIV-1 polymorphism: a challenge for vaccine development - A review. Mem Inst Oswaldo Cruz, 97: 143-150.

Morgado MG, Guimarães ML, Gripp CBG, Costa CI, Neves Jr I, Veloso VG, Linhares de Carvalho MI, Castello-Branco LR, Bastos FI, Kuiken C, Castilho EA, Galvão-Castro B, Bongertz V, The HEC AIDS Clin Res Group 1998. Molecular epidemiology of HIV in Brazil: high prevalence of B subtype and identification of a HIV-1 subtype D infection in Rio de Janeiro City. J AIDS Human Retrovirol 18: 488494. 
Nishimura Y, Igarashi T, Haigwood N, Sadjadpour R, Plishka RJ, Buckler-White A, Shibata R, Martin MA 2002. Determination of a statistically valid neutralization titer in plasma that confers protection against simian-human immunodeficiency virus challenge following passive transfer of hightitered neutralizing antibodies. J Virol 76: 2123-2130.

Parren PW, Marx PA, Hessell AJ, Luckay A, Harouse J, ChengMayer C, Moore JP, Burton DR 2001. Antibody protects macaques against vaginal challenge with a pathogenic R5 simian/human immunodeficiency virus at serum levels giving complete neutralization in vitro. J Virol 75: 8340-8347.

Pugach P, Kuhmann SE, Taylor J, Marozsan AJ, Snyder A, Ketas T, Wolinsky SM, Korber BT, Moore JP 2004. The prolonged culture of human immunodeficiency virus type 1 in primary lymphocytes increases its sensitivity to neutralization by soluble CD4. Virology 321: 8-22

Robert-Guroff M, Brown M, Gallo RC 1985. HTLV-III neutralising antibodies in patients with AIDS and AIDSrelated complex. Nature (London) 316: 72-74.

Ruprecht RM, Hofmann-Lehmann R, Smith-Franklin BA, Rasmussen RA, Liska V, Vlasak J, Xu W, Baba TW, Chenine AL, Cavacini LA, Posner MR, Katinger H, Stiegler G, Bernacky BJ, Rizvi TA, Schmidt R, Hill LR, Keeling ME, Montefiori DC, McClure HM 2001. Protection of neonatal macaques against experimental SHIV infection by human neutralizing monoclonal antibodies. Transfus Clin Biol 8: 350-358.

Vicente AC, Otsuki K, Silva NB, Castilho MC, Barros FS, Pieniazek D, Hu D, Rayfield MA, Bretas G, Tanuri A 2000. The HIV epidemic in the Amazon Basin is driven by prototypic and recombinant HIV-1 subtypes B and F. $J$ Acquir Immune Defic Syndr 23: 327-231.

Weber J, Fenyö EM, Beddows S, Kaleebu P, Bjorndal A 1996. Neutralization serotypes of human immunodeficiency virus type 1 field isolates are not predicted by genetic subtype. The WHO Network for HIV Isolation and Characterization. J Virol 70: 7827-7832.

Weiss RA, Clapham PR, Cheingsong-Popov R, Dalgleish AG, Carne CA, Weller IVD, Tedder RS 1985. Neutralisation of human T-lymphotropic virus type III by sera of AIDS and AIDS-risk patients. Nature (London) 316: 69-72.

Xiao Y, Dong X, Chen YH 2002. Neutralizing antibodies mechanism of neutralization and protective activity against HIV1. Immunol Res 25: 193-200.

Xu W, Hofmann-Lehmann R, McClure HM, Ruprecht RM 2002. Passive immunization with human neutralizing monoclonal antibodies: correlates of protective immunity against HIV. Vaccine 20: 1956-1960.

Zhang YJ, Hatziioannou T, Zang T, Braaten D, Luban J, Goff SP, Bieniasz PD 2002. Envelope-dependent, cyclophilinindependent effects of glycosaminoglycans on human immunodeficiency virus type 1 attachment and infection. $J$ Virol 76: 644-655.

Zolla-Pazner S 2004. Identifying epitopes of HIV-1 that induce protective antibodies. Nat Rev Immunol 4: 199-210.

Zolla-Pazner S, Gorny MK, Nyambi PN, VanCott TC, Nadas A 1999. Immunotyping of human immunodeficiency virus type 1 (HIV): an approach to immunologic classification of HIV. J Virol 73: 4042-4051. 
